\title{
Biological Activity of Wild Isolates of Entomopathogenic Nematodes to Horse- Chestnut Leaf Miner (Cameraria ohridella)
}

\author{
Joanna Matuska-Lyżwa ${ }^{1 *}$, Wiesław Kaca ${ }^{2}$, Paulina Żarnowiec ${ }^{2}$ \\ 'Department of Zoology and Biological Didactics, Institute of Biology, \\ ${ }^{2}$ Department of Microbiology, Institute of Biology, \\ The Jan Kochanowski University, Świętokrzyska 15, 25-406 Kielce, Poland
}

Received: 24 November 2014

Accepted: 11 December 2014

\begin{abstract}
One of the pests of white chestnut (Aesculus hippocastanum L.) is a horse-chestnut leaf miner (Cameraria ohridella). Effective methods of reducing the population of this butterfly are still under investigation. One of them is the use of insecticidal nematodes that occur naturally in the environment. This paper presents the results of the susceptibility of horse-chestnut leaf miner larvae on entomopathogenic nematodes of the genus Steinernema. The experiment was conducted at a temperature of $20^{\circ} \mathrm{C}$ and a dose initialized to 100 nematodes/insect. Applied nematodes were harvested from the greenery of Swietokrzyskie Province. The results of the analysis showed that the larvae Cameraria ohridella are susceptible to insecticide nematode invasion isolated from different sources. It was also shown that the efficiency of killing an insect by nematodes (extensiveness of invasion) is not correlated with the ability to reproduce or the viability of successive generations of insecticidal nematodes.
\end{abstract}

Keywords: biological protection, entomopathogenic nematodes, Cameraria ohridella

\section{Introduction}

Horse-chestnut leaf miner is a butterfly widely recognized as a pest of white chestnut (Aesculus hippocastanum L.). The worm affects both young and mature trees in places such as parks and green areas [1,2].

As a result of feeding, horse-chestnut leaf miner larvae formed brown spots on the leaves of trees (mine hollow in the crumb leaves), which are heavily infested, dry up, and fall off. With a large invasion of the pests, trees blooming in the fall could result in freezing caused by inadequate tree preparation for wintering. The first adults emerge in late April. We registered 3-4 generations of this pest per year. The pupae overwinter in fallen chestnut leaves and can withstand temperatures as high as $-21^{\circ} \mathrm{C}$, but nearly $90 \%$ of the pupae overwintering in the leaves may die from various causes $[3,4]$.

*e-mail: joannaujk@op.pl
The occurrence of horse-chestnut leaf miner already has been noted in almost all Polish territory (except for the northeastern border and mountains). Pest control and prevention consists primarily of removing and disposing of fallen leaves [5-7], but also microinjection of a special gel (endotherapy), large sticky traps placed on tree trunks, pheromone traps, soil injections, and suspending nesting boxes for insectivorous birds. However, most of the abovementioned methods are expensive or harmful to humans, beneficial insects (chemicals), and trees (microinjection causes problems in healing the wound, resulting in the possibility of penetration by other pathogens) [8-13].

One of the most novel methods in the fight against this pest is the use of insecticidal fungi or nematodes [14, 15].

Insecticidal nematodes occur naturally in soil, but their number is too low to reduce a large population of the pest without human intervention. Additionally, there is a tendency to selectively attack the select groups of insects. 
Hence the need for isolation of nematodes from soil (areas most at risk of a pest) and determine the degree of pathogenicity for a specific pest species in order to apply the most effective race. Previous studies have shown that native populations of nematodes are better suited to the prevailing conditions in the soil and have a higher efficiency than the nematodes from biological specimens [16].

The aim of this study was to evaluate the biological activity of the native populations of insecticidal nematodes against horse-chestnut leaf miner (Cameraria ohridella) occurring in the urban green areas of Kielce.

\section{Experimental Procedures}

Entomopathogenic nematodes and horse-chestnut leaf miner larvae obtained from 10 different urban green areas in Kielce (Slichowice, Karczowka, Bialogon, Kadzielnia Planty, Staszic park, and Wietrznia, as well as near the train station, the Regional Sanitary-Epidemiological Station, and the park near Sciegiennego Street; Fig. 1).

With each research area that contained white chestnut (Aesculus hippocastanum L.), horse-chestnut leaf miner live larvae were collected by a mechanical method. From each of these sites we also collected 50 soil samples from the soil layer $0-25 \mathrm{~cm}$ by Egner probe. This method ensures complete and uniform sampling of the study area, which allows for fairly actual spatial distribution of the density of entomopathogenic nematodes in the soil. Longitude and latitude of research positions of the species were determined using a computer application Geofinder (http://geofinder.web4you.com.pl/).
For insect traps we used honeycomb moth caterpillars (Galleria mellonella L.) with an average body weight of $140 \mathrm{mg}$ from the Department of Zoology and Biological Didactics. They were cultured in polypropylene containers on beeswax combs. The analyses also attended nematodes (Steinernema kraussei) taken from the floodplain forest in Klonowskie strip, as well as a control - nematodes with biopreparation Owinema ( $S$. feltiae). Entomopathogenic nematodes were harvested from soil samples in the laboratory using an insect trap method. Well-mixed soil samples were placed in polypropylene containers with a volume of $250 \mathrm{~cm}^{3}$, with two insects traps (caterpillars Galleria mellonella). Samples were then placed in a PL-EKO ST1 incubator at $20^{\circ} \mathrm{C}$ for 16 days. Every other day dead insects were removed from samples and replaced by live tracks. Dead insects were placed on migration sponges (author patent No. 212617) and kept in an incubator at $20^{\circ} \mathrm{C}$ for the time necessary to obtain nematode larvae. After leaving the body of the host, nematodes were collected into tissue culture flasks and stored in the filtered water at $4^{\circ} \mathrm{C}$. Select isolates of nematodes were determined using a key for determining the species (morphometric analysis of all developmental stages of the nematodes examined using a micrometer eyepiece) and by PCR analysis carried out as previously described. Research on the invasive nematode terms to horse-chestnut leaf miner was carried out on Petri dishes in the incubator at $20^{\circ} \mathrm{C}$. To infect insect larvae an invasive dose of 100 nematodes per insect was used. Determined basic parameters of nematode invasive techniques such as insect mortality, extent of the invasion, and reproduction of nematodes. In order to investigate the extent of the invasion (the percentage ratio of insect infestation by insecticide

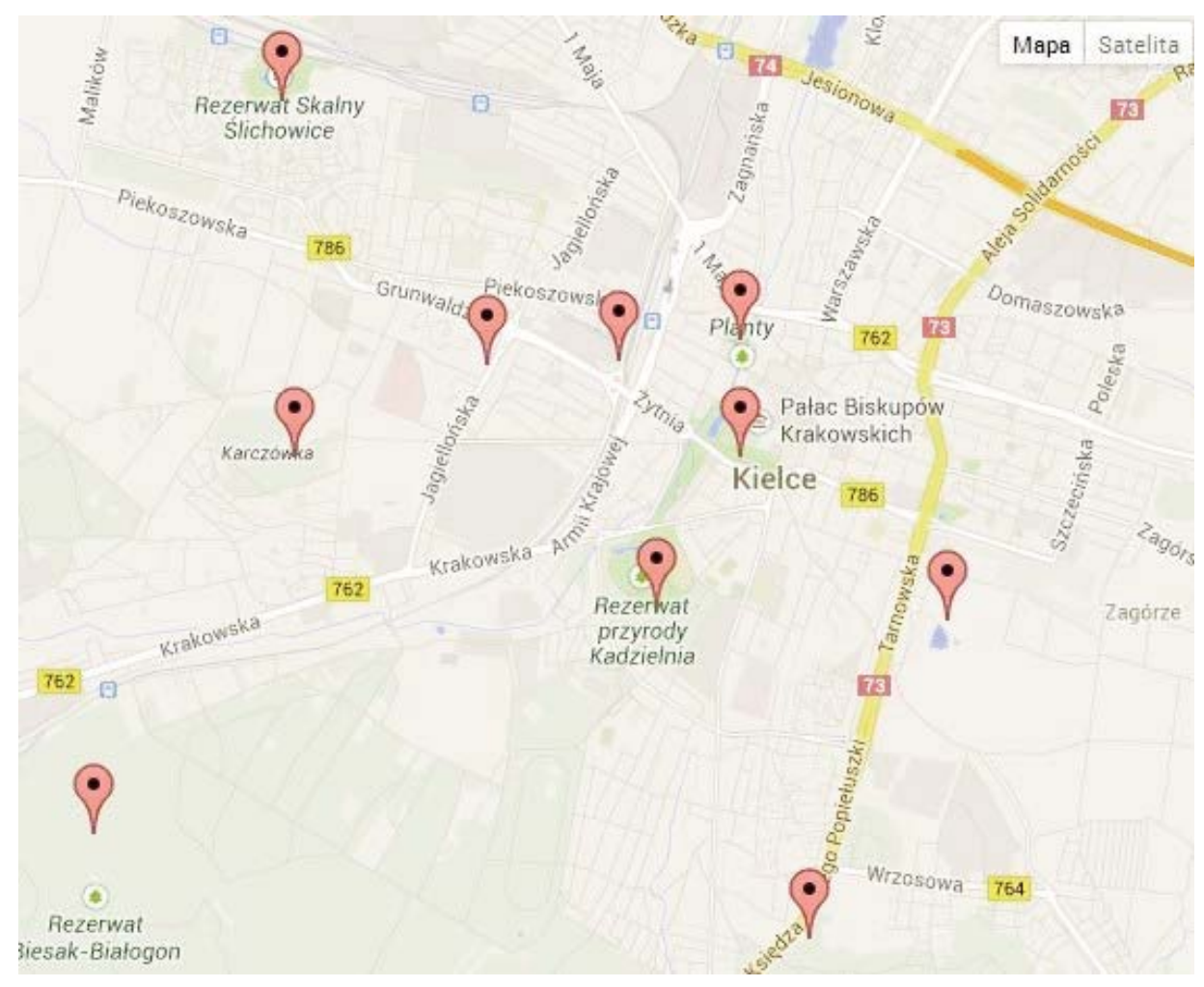

Fig. 1. Research areas. 
Table 1. Invasive tested entomopathogenic nematode isolates.

\begin{tabular}{|c|c|c|c|c|}
\hline Analyzed samples & $\begin{array}{c}\text { Control sample "Owinema" } \\
\text { (S. feltiae) }\end{array}$ & $\begin{array}{c}267 \\
\text { (S. kraussei) }\end{array}$ & $\begin{array}{c}296 \\
\text { (S. carpocapsae) }\end{array}$ & $\begin{array}{c}297 \\
\text { (Steinernema sp.) }\end{array}$ \\
\hline Overall mortality of insects [\%] & 60 & 80 & 80 & 70 \\
\hline Extensiveness of invasion [\%] & $60^{\mathrm{a}}$ & $80^{\mathrm{b}}$ & 856 & 1405 \\
\hline $\begin{array}{c}\text { The number of migrating larvae of } \\
\text { nematodes from 1piece of insect }\end{array}$ & 1170 & $460^{\mathrm{b}}$ & $364^{\mathrm{c}}$ & $1064^{\mathrm{d}}$ \\
\hline $\begin{array}{c}\text { The number of migrating larvae of } \\
\text { nematodes larvae capable of another } \\
\text { invasion / live / from lpiece of insect }\end{array}$ & $951^{\mathrm{a}}$ & 856 & \\
\hline
\end{tabular}

different letters in the columns denote significant differences at the $\mathrm{p}<0.05$

nematodes), dead insects were dissected within two days of their death.

The analysis of nematode reproduction was carried out for 40 days after the first appearance of invasive larvae in an external artificial environment (Petri dish). We rated the total number of larvae that managed to leave the body of the host on the day of collection and the number of live larvae capable of following the invasion.

For statistical analysis, univariate analysis of variance was used (UNIANOVA). The experiment was repeated three times.

\section{Results and Discussion}

\section{Isolation and Analysis of Species}

Six of the 10 analyzed sites showed the presence of soil nematodes, and two areas were characterized by the presence of insecticide nematodes: Nematode isolate number 296, harvested from the area of the Regional SanitaryEpidemiological Station, and 297 near the railway station. Morphometric and molecular analysis showed that isolate number 296 is a species of Steinernema carpocapsae. Isolate numer 297 was identified to the genus Steinernema sp.

\section{Invasiveness}

The highest horse-chestnut leaf miner mortality and extensiveness of nematode invasions was observed in samples 267 and 296, while the control sample and the nematodes from sample 297 were characterized by lower values (Table 1). These differences may be caused by various factors such as species differences or different adaptation of tested nematode isolates (origin, other than in the wild host species and other than the environment temperature conditions, etc.).

Analyzing reproduction (number of migratory larvae of nematodes from 1pc. of insect) of tested nematode isolates demonstrated that the most productive were the nematodes from isolate number 297, and the least productive were nematode isolate numbers 267 and 296.

Considering both parameters was observed that the effectiveness of killing an insect (extensiveness of inva- sion) is not correlated with the ability of reproduction, and especially with the vitality of successive generations. Isolate number 297 was characterized by the lowest of the tested extensiveness of invasion and the highest number of migrating larvae of nematodes capable of another invasion. Nematodes from the control sample (nematodes from biopreparation) showed average extent of their invasion, but less reproduction than isolate number 297. This fact can be explained by a deliberate focus on the one-off effectiveness of biopreparation, but the ability to reproduce and survive of is no longer a priority feature here.

In summary, urban green areas in Kielce, on which feed horse-chestnut leaf miner, the soil environment are also houses natural populations of entomopathogenic nematodes. Their effectiveness toward this pest confirms findings of other researchers [15].

The existing literature also shows that local populations of nematodes have a higher biological activity to the host than isolates from other regions $[16,17]$. It can therefore be assumed that the nematode adaptation to the environment and the changes that occur in it - make that these animals more resilient and with more invasive power than nematodes from other sources.

In the case of horse-chestnut leaf miner, the high activity of wild nematodes isolates (natural populations) against larvae of this pest, limited only by the barrier that is the soil surface (as entomopathogenic nematode larvae are below the soil surface, whereas horse-chestnut leaf miner larvae are in the chestnut leaves on a tree, and those fallen to the ground).

Therefore, with the development of new plant protection products on the basis of insecticidal nematodes, many aspects such as pest species, species and origin of the main "biocidal agent" (nematodes belonging to the created biopreparation) and the form of preparation application should be taken into consideration. Current capabilities have allowed the creation of biologicals in different formulations, e.g. liquid, semi-liquid, powder, or gel. The last one makes it possible to use the product directly on the foliage of plants [18].

Studies on diversity and invasiveness of nematodes derived from the natural environment are leading topics of insecticidal nematodes. Continuing this theme will make better use of their potential as insecticides. 


\section{Conclusions}

1. Urban green areas in Kielce, on which horse-chestnut leaf miner feed, the soil environment also includes natural populations of entomopathogenic nematodes.

2. The effectiveness of killing an insect (extensiveness of invasion) is not correlated with the ability of reproduction and vitality of successive generations.

\section{Acknowledgements}

This project was realized with financial support from the Swietokrzyskie Provincial Government.

\section{References}

1. CICHON S. Studies on the occurrence, biology, harmfulness and fighting horse-chestnut leaf miner (Cameralia ohridella Deschka \& Dymić) new for Polish pest of white chestnut (Aesculus hippocastanum). PhD dissertation. UR, Kraków, 33, 2008.

2. KROPCZYŃSKA-LINKIEWICZ D., TOMCZYK A., POLEWCZYŃSKA E. Susceptibility chestnut grafted on different rootstocks with white chestnut (Aesculus hippocastanum L.) and red chestnut (Aesculus x carnea Hayne) on horse-chestnut leaf miner (Cameraria ohridella Deschka \& Dimić). Prog. Plant Prot. 48, (4), 1351, 2008.

3. BENGTSSON B.A., JOHANSSON R. Encyclopedia of the Swedish flora and fauna. Butterflies: Roeslerstammiidae Lyonetiidae. Lepidoptera: Roeslerstammiidae Lyonetiidae. ArtDatabanken, SLU, Uppsala. pp. 494, 2011.

4. LEES, D. C., LOPEZ-VAAMONDE, C., AUGUSTIN, S. Cameraria ohridella Deschka \& Dimić, 1986. Encyclopedia of Life. Available from:

http://eolspecies.lifedesks.org/pages/8675, 2013.

5. BARANOWSKI T. The effect of treatments on the health of the trees in cities. Prog. Plant Prot. 50, (4), 1569, 2010.

6. BARANOWSKI T., DANKOWSKA E. The integrated protection of horse-chestnuts against horse chestnut leafminer (Cameraria ohridella Deschka \& Dimić), Prog. Plant Prot 52, (4), 807, 2012.

7. OSZAKO T. Methodological basis to fight the horse chestnut leaf miner. Forest Research Papers 2, 130, 2004.
8. BARANOWSKI T. Protection of trees in the city. Green Town and Country. Conference materials. Techniques and Technologies for Landscape Architecture, Kalsk, pp. 26-29, 2009.

9. BARANOWSKI T., DANKOWSKA E. Effectiveness of pheromone traps in catching horse chestnut leaf miner butterflies (Cameraria ohridella). Prog. Plant Prot. 51, (2), 783, 2011.

10. GŁOWACKA B., LIPIŃSKI S., TARWACKI G. Ability to protect white chestnut (Aesculus hippocastanum L.) before the horse chestnut leaf miner (Cameraria ohridella Deschka \& Dimić). Forest Research Papers, 70, (4), 317, 2009, DOI: 10.2478/v10111-009-0030-1.

11. ŁABANOWSKI G., SOIKA G., ŚWITOSAWSKI J. The effectiveness of Treex 200 SL in protecting white chestnut against horse chestnut leaf miner (Cameraria ohridella). Prog. Plant Prot. 48, (3), 913, 2008.

12. OSZAKO T., SIEWNIAK M., SIEWNIAK M. The negative influence of the so-called "injection" measure on threatened horse chestnut trees. Alien Invasive Species and International Trade Edited by Hugh Evans and Tomasz Oszako: Warszawa, pp 129-132, 2007.

13. SIEWNIAK M., OSZAKO T., SIEWNIAK M. Negative stem anatomical changes caused by the attempt to combat horse chestnut leaf miner by "gelling" method. Bulletin of the Polish Disinfection, Debian bug squashing and rat Workers Association, 3, (46), 26, 2006.

14. METLA Z., VOITKĀNE S., SEŠĶĒNA R., PETROVA V., JANKEVICA L. Presence of entomopathogenic fungi and bacteria in Latvian population of horse-chestnut leaf miner Cameraria ohridella. Acta Biol. Univ. Daugavp., 13, (1), 69, 2013.

15. DZIĘGIELEWSKA M. Insecticidal nematodes (Steinernematidae, Heterrorhabditidae) as a natural resistance factor in an urban environment. Proc ECOpole, 2, (2), 433, 2008.

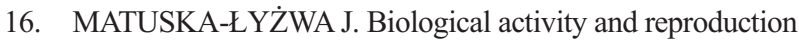
of insecticidal nematodes selected agrocoenoses, Proc ECOpole, 6, (2), 755, 2012. DOI:10.2429/proc.2012.6(2)104

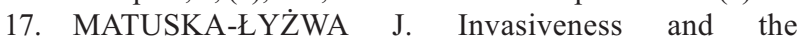
Morphometry of Steinernema feltiae from Different Agrocoenoses of Poland. Ecol. Chem. and Eng. 20, (4-5), $565,2013$.

18. TOMALAK M., SOSNOWSKA D., LIPA J. Trends in the development of biological plant protection., Prog. Plant Prot., 50, (4), 1650, 2010. 